\title{
KONGRESSE UND MITTEILUNGEN
}

\author{
XIII. Congress of the International Society of Haematology \\ Munich, August 24th - 29th, 1970
}

The Congress Committee XIII Congress of the International Society of Hematology extends a very cordial invitation to all physicians and scientists interested in hematology and allied topics to attend and contribute to this meeting to be held from August 24th -29th, 1970 in Munich, Germany. President L. Heilmeyer.

\section{Main scientific topics}

- Molecular aspects of blood cell metabolism with special emphasis on disturbances of heme and globin biosynthesis.

- Kinetics of hemopoietic cell differentiation, proliferation and maturation.

- Humoral and neural factors regulating hemopoietic homeostasis.

- Use of radioactive isotopes and of computer technics in diagnosis of hematological disorders.

- Environmental factors in pathogenesis, course and treatment of hemopoietic disorders.

- Chemotherapy, immunotherapy and radiotherapy of leukemia and malignant lymphomas.

- Immunological aspects of blood coagulation and hemorrhagic disorders.

- Isolation, preservation, storage and transplantation of bone marrow and blood cells.

\section{Exhibitions}

- Industrial exhibition.

- Instruments.

- Pharmaceuticals.

- Scientific exhibition.

- Art exhibition.

- Art and medicine.

All inquiries to: Secretariat of the XIII Congress of the International Society of Hematology, 8 München 12, Postfach 200, Germany. Telephone: (0811) 76711.

\section{ERRATA}

Zur Arbeit: Döll, W. und K.-D. Fischer: Zum bakteriologischen Nachweis von Krankheitserregern im strömenden Blut mit Hilfe von polyanetholsulfosaurem Natrium („Liquoid“), in Blut XVII, Heft 6, 1968:

1. Seite 328 Abb. 1 c: richtig Escherichia coli

2. Seite 335 Literaturangaben Nr. 2 und 7: richtig Boll. Ist. sieroterap. milan. 